ISSN 0258-7122 (Print), 2408-8293 (Online)

Bangladesh J. Agril. Res. 44(3): 387-399, September 2019

\title{
EFFECTS OF TILLAGE PRACTICES AND NUTRIENT MANAGEMENT ON CROP PRODUCTIVITY AND PROFITABILITY IN JUTE-T. AMAN RICE- ONION CROPPING SYSTEM
}

\author{
N. SALAHIN ${ }^{1}$, M. K. AlaM ${ }^{2}$, N. C. SHIL ${ }^{3}$ \\ A. T. M. A. I. MONDOL ${ }^{4}$ AND M. J. ALAM ${ }^{5}$
}

\begin{abstract}
Conservation agriculture (CA) with appropriate nutrient management can help increase crop production, improve soil health and bring economic return. An experiment was conducted at farmer's field of Rajbari district under Low Ganges River Floodplain (AEZ-12) during 2017-2018 to evaluate the effects of tillage and nutrient management on the system productivity and profitability in the jute - T. Aman rice- onion cropping system. Strip tillage (ST) for jute, nonpuddling for T. Aman rice and one pass minimum tillage (MT) for onion was contrasted with conventional crop establishment practice (CT). Four different nutrient management practices were $\mathrm{NM}_{1}$ : farmer's practice $(\mathrm{FP}), \mathrm{NM}_{2}$ : soil test based (STB) fertilizer, $\mathrm{NM}_{3}: 25 \%$ extra of STB and $\mathrm{NM}_{4}$ : organic amendments (20\% nutrients from cowdung). The experiment was laid out in a split-plot design with three replications by assigning tillage practices in main plots and nutrient management in sub-plots. The yield attributes of jute, T. Aman rice and onion responded similarly to tillage practices. On the other hand, the system productivity and yield of component crops varied due to different nutrient management practices $(\mathrm{p}<0.05)$. The highest fibre yield of jute $\left(3.64 \mathrm{t} \mathrm{ha}^{-1}\right)$ was obtained in $25 \%$ extra of STB fertilizer dose; the highest T. Aman yield $(6.02 \mathrm{t}$ $\left.\mathrm{ha}^{-1}\right)$ and the highest onion bulb yield $\left(16.0 \mathrm{t} \mathrm{ha}^{-1}\right)$ in $20 \%$ organic nutrient management, followed by $25 \%$ extra of STB fertilizer dose. The highest system productivity was also produced by $20 \%$ organic amendments $\left(33.6 \mathrm{t} \mathrm{ha}^{-1}\right)$, followed by $25 \%$ extra of STB fertilizer dose $\left(32.3 \mathrm{t} \mathrm{ha}^{-1}\right)$. The lowest yield of crops and system productivity was recorded in FP $\left(28.6 \mathrm{t} \mathrm{ha}^{-1}\right)$. The increased yield of T. Aman rice and onion in $20 \%$ organic amendment by cowdung and $\mathrm{ST}$ resulted in the highest net return (NR) and benefit-cost ratio (BCR), while $25 \%$ extra of STB and FP under CT gave the lowest NR and BCR. Residual nutrient from successive use of cowdung combined with chemical fertilizers outperformed other management practices in terms of crop yield and economic return.
\end{abstract}

Keywords: Benefit-cost ratio; cropping system productivity; minimal soil disturbance; nutrient management; strip planting

\section{Introduction}

In general, agriculture in Bangladesh depicts excessive tillage, crop residue removal, imbalance fertilization, etc. that degraded soil health with accelerated

${ }^{1-5}$ Soil Science Division, Bangladesh Agricultural Research Institute (BARI), Gazipur1701, Bangladesh. 
decomposition of soil organic matter (SOM).Cropping intensity has increasedover time by increasing puddled rice production (BBS, 2012). Consequently, most of the soils contain less than $1.5 \%$ SOM, and some soils have even less than 1\% SOM (BARC, 2018). The sub-tropical humid climate causes rapid breakdown of SOM by heterotrophic microbes; consequently, nutrients loss occurs through different processes, viz. leaching, volatilization, runoff etc. The low SOM is a cause of low productivity and is considered as a serious threat to the sustainability of agriculture in Bangladesh (Jahiruddin and Satter, 2010). Organic matter (OM) depletion occurs in high land and medium high land soils (WRC, 2008-2009), while OM content has little increased in low land soils with rice-rice cropping pattern (BRRI, 2008). Intensification of agricultural land use with high expansion of modern crop varieties has increased remarkably which has exhausted nutrients from soil. Thus, with advancement of time, soil fertility has declined and chronologically the deficiency of nitrogen, phosphorus, potassium, sulphur, zinc and boron has arisen in the soils (Jahiruddin and Satter, 2010).

Most agricultural soils have become vulnerable to tillage-stimulated rapid loss of SOM in the coarse texture soils (Stewart et al., 2007). As the delta country has most of the cropping systems based on rice (Alam et al., 2016b), the puddling of soil for rice crop establishment causes heavy havoc on soil properties by destroying structure of soil. In addition, puddling of soil accelerates decomposition of SOM, increases greenhouse gas emissions (GHGs)and nitrogen loss (Alam et al., 2019b) and inflicts increased costs for upland crop establishment (Bell et al., 2019).In contrary, minimum or zero tillage practice increases SOM levels (Busari and Salako, 2013),enriches nutrients in soils (Alam, 2018) and water retention capacity (Aziz et al., 2013), and decreases production costs (Salahin, 2017) and GHGs (Alam et al., 2019b) by reducing fuel use for intensive tillage and irrigation requirements (Johansen et al., 2012). There are many researches on zero and minimum tillage that has been proved as a greater technique to increase SOM, microbial activity, total $\mathrm{N}$, and extractable $\mathrm{P}$, $\mathrm{S}, \mathrm{Zn}$ and $\mathrm{B}$ at the soil surface compared to conventional tillage (Alam et al., 2016a; Vu et al., 2009). Besides, non-puddled rice crop establishment has been recently developed and performed well in yield, soil health, economics and climate change mitigation (Bell et al., 2019; Salahin, 2017; Alam, 2018; Alam et $a l ., 2019 \mathrm{a})$. In these situations, the idea of conservation agriculture (CA) in ricebased intensive cropping systems through employing minimal soil disturbance, crop residue retention with suitable crop rotations (Kassam et. al., 2009) has emergedas a holistic alternative agricultural system for its production sustainability, economic viability, environment friendly approach. However, conservation agriculture (CA) is inadequately developed for intensive upland-rice cropping system widely practiced in Bangladesh (Alam et al., 2016b; Salahin, 2017) and the experimentation of $\mathrm{CA}$ with different nutrient management practices on soil properties and crop yields under jute-T. Aman rice- onion 
cropping systems has not been examined in the poorly fertile soils of Bangladesh. With a view to address such issues, the present study was undertaken with the following objectives:

i). to find out the suitable combination of tillage practices and nutrient management for maximizing the crop yield in the jute- T. Aman- onion cropping system, and

iii). to evaluate the system productivity and economic profitability in this system.

\section{Materials and Methods}

\section{Description of experimental site}

The experiment was done at farmer's field of Rajbari district during 2017-2018.It belongs to the agro-ecological zone "Low Ganges River Floodplain" (AEZ-12; located at $23^{\circ} 48 " 35^{\prime \prime} \mathrm{N}$ and $89^{\circ} 25^{\prime} 55^{\prime \prime} \mathrm{E}$, at $11.0 \mathrm{~m}$ above the sea level. Initial soil characteristics of the experimental field were determined and information of soil texture, bulk density, soil $\mathrm{pH}$, organic matter, total $\mathrm{N}$, available $\mathrm{P}, \mathrm{K}, \mathrm{S}, \mathrm{Zn}$, and $\mathrm{B}$ contents at $0-15 \mathrm{~cm}$ soil depth are presented in Table 1 .

Table 1. Initial soil characteristics of the experimental field, Rajbari district $(0-15 \mathrm{~cm})$

\begin{tabular}{|c|c|c|c|c|c|c|c|c|c|}
\hline \multirow{3}{*}{$\mathrm{pH}$} & SOM & TN & & Availa & le nutrie & & & \multirow{4}{*}{$\begin{array}{c}\text { Textural } \\
\text { class }\end{array}$} & \multirow{2}{*}{$\begin{array}{c}\text { Bulk } \\
\text { density }\end{array}$} \\
\hline & \multirow{2}{*}{\multicolumn{2}{|c|}{$\%$}} & $\mathrm{~K}$ & $P$ & $S$ & $\mathrm{Zn}$ & B & & \\
\hline & & & $\begin{array}{c}\text { meq } 100 \mathrm{~g} \\
\text { soil }^{-1}\end{array}$ & \multicolumn{4}{|c|}{$\mathrm{mg} \mathrm{kg}^{-1}$} & & $\left(\mathrm{~g} \mathrm{~cm}^{-3}\right)$ \\
\hline 8.1 & 1.09 & 0.060 & 0.15 & 7.2 & 13 & 0.25 & 0.15 & & \\
\hline $\begin{array}{l}\text { Slightly } \\
\text { alkaline }\end{array}$ & Low & \begin{tabular}{|l|} 
Very \\
Low
\end{tabular} & Medium & Low & $\begin{array}{c}\text { Mediu } \\
\mathrm{m}\end{array}$ & $\begin{array}{l}\text { Very } \\
\text { Low }\end{array}$ & Low & $\begin{array}{l}\text { Sandy } \\
\text { loam }\end{array}$ & 1.53 \\
\hline
\end{tabular}

\section{Treatments and design}

The unit experimental plot area was $7.2 \mathrm{~m} \times 4.5 \mathrm{~m}$ and the design of the experiment was split-plot with three replications. Tillage practices such as, $\mathrm{T}_{1}$ : conventional tillage (CT) and $\mathrm{T}_{2}$ : minimum tillage (MT)/strip tillage (ST)/nonpuddling was assigned in main plots and four nutrient management practices such as $\mathrm{NM}_{1}$ : farmer's practice ( $\left.\mathrm{FP}\right), \mathrm{NM}_{2}$ : soil test based recommended fertilizer (100\% STB as per Fertilizer Recommendation Guide-FRG, all from chemical fertilizers), $\mathrm{NM}_{3}: 25 \%$ extra of STB as per FRG, all from chemical fertilizers and $\mathrm{NM}_{4}$ : $80 \%$ from chemical fertilizer and the $20 \%$ nutrients supplemented with cowdung manure were allotted in sub-plots. Details of the treatments are given in Table 2. 


\section{Sowing/transplanting}

Jute seed (cv. Nabin) was sown on 11 May, 2017 maintaining $25 \mathrm{~cm} \times 7-10 \mathrm{~cm}$ spacing, T. Aman rice seedlings (cv. BRRIdhan 72) were transplanted on 10 August 2017 maintaining $20 \mathrm{~cm} \times 20 \mathrm{~cm}$ spacing and onion seedlings (cv. King) were transplanted on 23 January 2018 at $15 \mathrm{~cm}$ apart from row to row and $10 \mathrm{~cm}$ apart from plant to plant.

Table 2. Different tillage and nutrient management practices along with fertilizer application method for component crops of jute-T. Aman- onion cropping system

\begin{tabular}{|c|c|c|c|c|}
\hline \multirow{2}{*}{\multicolumn{2}{|c|}{ Treatments }} & \multicolumn{2}{|r|}{ Crops } & \multirow[b]{2}{*}{ Onion } \\
\hline & & \multirow{2}{*}{$\begin{array}{c}\text { Jute } \\
4-5 \text { pass of } \\
\text { power tiller } \\
\text { machine } \\
\text { followed by 2-3 } \\
\text { laddering }\end{array}$} & \multirow[b]{2}{*}{\begin{tabular}{|c|} 
T. Aman \\
Puddling was done by \\
$4-5$ wet tillage \\
operations using \\
power tiller machine \\
followed by 2-3 \\
laddering
\end{tabular}} & \\
\hline $\begin{array}{l}\text { Tillage } \\
\text { practices }\end{array}$ & $\begin{array}{c}\text { Conventional } \\
\text { tillage/puddling }\end{array}$ & & & $\begin{array}{c}4-5 \text { pass of } \\
\text { power tiller } \\
\text { machine } \\
\text { followed by 2-3 } \\
\text { laddering }\end{array}$ \\
\hline & $\begin{array}{l}\text { Minimum } \\
\text { tillage (MT)/ } \\
\text { Strip tillage } \\
\quad(\mathrm{ST})\end{array}$ & $\begin{array}{l}\text { ST was done by } \\
\text { one pass with } \\
\text { PTOS using } \\
\text { rotating blades } \\
\text { maintaining } 25 \\
\text { cm spacing from } \\
\text { row to row }\end{array}$ & $\begin{array}{l}\text { Non-puddling; Strip } \\
\text { was done by one pass } \\
\text { with PTOS using } \\
\text { rotating blades } \\
\text { maintaining } 20 \mathrm{~cm} \\
\text { spacing from row to } \\
\text { row around } 18-24 \\
\text { hours before } \\
\text { transplanting rice; } \\
\text { Full puddling was not } \\
\text { done }\end{array}$ & $\begin{array}{l}\text { MT was done by } \\
\text { one pass with } \\
\text { power tiller } \\
\text { operated seeder } \\
\text { (PTOS }\end{array}$ \\
\hline $\begin{array}{c}\text { Nutrient } \\
\text { Management } \\
\text { practices }\end{array}$ & $\begin{array}{c}\mathrm{NM}_{1}: \text { Farmers } \\
\text { practice }(\mathrm{FP})\end{array}$ & $\begin{array}{c}\text { Fertilizer dose: } \\
\mathrm{N}_{180}, \mathrm{P}_{10}, \mathrm{~K}_{45} \\
\text { and } \mathrm{S}_{8} \mathrm{~kg} \mathrm{ha}^{-1} \\
\\
\text { Application } \\
\text { method: } \\
\text { 1/2 urea was } \\
\text { applied with all } \\
\text { other fertilizers } \\
\text { during final land } \\
\text { preparation and } \\
\text { 1/2 urea was at } \\
\text { 30 DAS }\end{array}$ & $\begin{array}{c}\text { Fertilizer dose: } \mathrm{N}_{120} \\
\mathrm{P}_{10}, \mathrm{~K}_{40}, \mathrm{~S}_{6} \text { and } \mathrm{Zn}_{1} \\
\mathrm{~kg} \mathrm{ha}^{-1} \\
\\
\text { Application method: } \\
\text { 1/2 urea was applied } \\
\text { with all other } \\
\text { fertilizers during final } \\
\text { land preparation and } \\
1 / 2 \text { urea was at } 36 \\
\text { DAT }\end{array}$ & $\begin{array}{c}\text { Fertilizer dose: } \\
\mathrm{N}_{140}, \mathrm{P}_{30}, \mathrm{~K}_{60} \\
\text { and } \mathrm{S}_{16} \mathrm{~kg} \mathrm{ha}^{-1} \\
\\
\text { Application } \\
\text { method: } \\
\text { 1/2 urea was } \\
\text { applied with all } \\
\text { other fertilizers } \\
\text { during final land } \\
\text { preparation and } \\
1 / 2 \text { urea was at } 35 \\
\text { DAT }\end{array}$ \\
\hline
\end{tabular}




\begin{tabular}{|c|c|c|c|}
\hline \multirow{2}{*}{ Treatments } & \multicolumn{2}{|r|}{ Crops } & \multirow[b]{2}{*}{ Onion } \\
\hline & Jute & T. Aman & \\
\hline $\begin{array}{l}\mathrm{NM}_{2} \text { : Soil test } \\
\text { based } \\
\text { recommended } \\
\text { fertilizer (100\% } \\
\text { STB as per } \\
\text { FRG-2012, all } \\
\text { nutrients from } \\
\text { chemical } \\
\text { fertilizers) }\end{array}$ & $\begin{array}{c}\text { STB dose: } \mathrm{N}_{153}, \\
\mathrm{P}_{13}, \mathrm{~K}_{72}, \mathrm{~S}_{12}, \\
\mathrm{Zn}_{1.0} \text { and } \mathrm{B}_{0.5} \mathrm{~kg} \\
\text { ha }^{-1} \\
\text { Application } \\
\text { method: Urea } \\
\text { was applied in } \\
\text { two equal splits } \\
\text { at 25 and 50 } \\
\text { days after } \\
\text { sowing (DAS) }\end{array}$ & \begin{tabular}{|} 
STB dose: $\mathrm{N}_{100}, \mathrm{P}_{13}$, \\
$\mathrm{K}_{47}, \mathrm{~S}_{9}, \mathrm{Zn}_{2}$ and $\mathrm{B}_{0.5}$ \\
$\qquad \mathrm{~kg} \mathrm{ha}^{-1}$ \\
\\
Application method: \\
all other fertilizers \\
except urea were \\
applied during final \\
land preparation. \\
Urea in 3 equal splits- \\
the $1 / 3^{\text {rd }}$ at 4 DAT, \\
the second split at 35 \\
DAT and the third \\
split at 48 DAT
\end{tabular} & $\begin{array}{l}\text { STB dose: } \mathrm{N}_{100}, \\
\mathrm{P}_{46}, \mathrm{~K}_{94}, \mathrm{~S}_{23}, \mathrm{Zn}_{4} \\
\text { and } \mathrm{B}_{1.5} \mathrm{~kg} \mathrm{ha}^{-1} \\
\text { Application } \\
\text { method: all } \\
\text { required } \\
\text { fertilizers in full } \\
\text { dose and } 1 / 2 \text { urea } \\
\text { and MoP was } \\
\text { applied as basal } \\
\text { dose whereas the } \\
\text { rest urea and } \\
\text { MoP applied in } 2 \\
\text { equal splits at } 25 \\
\text { and } 50 \text { days after } \\
\text { transplanting }\end{array}$ \\
\hline $\begin{array}{l}\mathrm{NM}_{3}: 25 \% \\
\text { extra of STB as } \\
\text { per FRG-2012, } \\
\text { all nutrients } \\
\text { from chemical } \\
\text { fertilizers }\end{array}$ & $\begin{array}{c}\text { Fertilizer dose: } \\
\mathrm{N}_{191}, \mathrm{P}_{16}, \mathrm{~K}_{90} \\
\mathrm{~S}_{15}, \mathrm{Zn}_{1.3} \text { and } \\
\mathrm{B}_{0.63} \mathrm{~kg} \mathrm{ha}^{-1} \\
\\
\text { Application } \\
\text { method: } \text { Same } \\
\text { as } \mathrm{NM}_{2} \\
\end{array}$ & $\begin{array}{c}\text { Fertilizer dose: } \mathrm{N}_{125} \\
\mathrm{P}_{16}, \mathrm{~K}_{59}, \mathrm{~S}_{11}, \mathrm{Zn}_{2.5} \text { and } \\
\mathrm{B}_{0.63} \mathrm{~kg} \mathrm{ha}^{-1} \\
\\
\text { Application method: } \\
\text { Same as } \mathrm{NM}_{2}\end{array}$ & $\begin{array}{l}\text { Fertilizer dose: } \\
\mathrm{N}_{125}, \mathrm{P}_{58}, \mathrm{~K}_{118}, \\
\mathrm{~S}_{29}, \mathrm{Zn}_{5} \text { and } \mathrm{B}_{1.9} \\
\mathrm{~kg} \mathrm{ha}^{-1} \\
\\
\text { Application } \\
\text { method: } \text { Same as } \\
\mathrm{NM}_{2}\end{array}$ \\
\hline $\begin{array}{l}\mathrm{NM}_{4}: 80 \% \\
\text { from chemical } \\
\text { fertilizer and } \\
\text { the } 20 \% \\
\text { nutrients } \\
\text { supplemented } \\
\text { with cowdung } \\
\text { manure @ } 5 \mathrm{t} \\
\text { ha }^{-1}\end{array}$ & \begin{tabular}{|} 
Fertilizer dose: \\
$\mathrm{N}_{122}, \mathrm{P}_{10}, \mathrm{~K}_{58}$, \\
$\mathrm{S}_{10}, \mathrm{Zn}_{0.8}$ and \\
$\mathrm{B}_{0.4} \mathrm{~kg} \mathrm{ha}^{-1}$ from \\
$\mathrm{CF} \& \mathrm{~N}_{31}, \mathrm{P}_{3}$, \\
$\mathrm{K}_{14}, \mathrm{~S}_{2}, \mathrm{Zn}_{0.2}$ \\
and $\mathrm{B}_{0.2} \mathrm{~kg} \mathrm{ha}^{-1}$ \\
from cowdung \\
\\
Application \\
method: \\
chemical \\
fertilizers were \\
applied as same \\
as NM \\
organic manereas \\
(cowdung) was \\
applied before \\
land preparation
\end{tabular} & $\begin{array}{l}\text { Application method: } \\
\text { chemical fertilizers } \\
\text { were applied as same } \\
\text { as } \mathrm{NM}_{2} \text { whereas } \\
\text { organic manure } \\
\text { (cowdung) was } \\
\text { applied before land } \\
\text { preparation }\end{array}$ & $\begin{array}{c}\text { Fertilizer dose: } \\
\mathrm{N}_{80}, \mathrm{P}_{37}, \mathrm{~K}_{75}, \mathrm{~S}_{18}, \\
\mathrm{Zn}_{3} \text { and } \mathrm{B}_{1.2} \mathrm{~kg} \\
\mathrm{ha}^{-1} \text { from } \mathrm{CF} \\
\& \mathrm{~N}_{20}, \mathrm{P}_{10}, \mathrm{~K}_{20}, \\
\mathrm{~S}_{5}, \mathrm{Zn}_{1} \text { and } \mathrm{B}_{0.3} \\
\mathrm{~kg} \mathrm{ha}^{-1} \text { from } \\
\text { cowdung } \\
\text { Application } \\
\text { method: } \\
\text { chemical } \\
\text { fertilizers }(\mathrm{CF} \text { ) } \\
\text { were applied as } \\
\text { same as NM } \\
\text { whereas organic } \\
\text { manure } \\
\text { (cowdung) was } \\
\text { applied before } \\
\text { land preparation }\end{array}$ \\
\hline
\end{tabular}




\section{Crop harvesting and data collection}

Jute was harvested on 31 July 2017, T. Aman rice on 03 December 2017 and onion was harvested on 08 April 2018. Two (2) $\mathrm{m}^{2}$ area from each plot was selected immediately after sowing/transplanting for data collection. Ten plants of each plot were selected for yield attributes. Thousand grain weight of T. Aman was measured plot-wise. The plants were cut, then threshed, cleaned, sun-dried and weighed of grain and straw separately from $2 \mathrm{~m}^{2}$ area of each plot. Finally, the grain and straw were converted into $\mathrm{tha}^{-1}$.

\section{Statistical analysis}

The effects of tillage practices and nutrient management approaches on yield and economics were assessed using a two-factor analysis of variance. All data were statistically analysed with SPSS (Statistical Package for the Social Sciences) software package version 21 (SPSS Inc., Chicago, IL, USA). Means were compared by using least significant difference (LSD) atp $<0.05$.

\section{Results and Discussion}

\section{$1^{\text {st }}$ Crop: Jute}

Effects of tillage and nutrient management on plant population, plant height and fibre yield of jute

Regardless of tillage methods, different nutrient management showed significant variations on the plant height as well as fibre yield of jute (Table 3). The highest plant height $(229 \mathrm{~cm})$ was recorded in $25 \%$ extra of STB which was statistically identical to $20 \%$ organic amended with $80 \%$ CF but different from FP and STB. The highest fibre yield was obtained from $25 \%$ extra of STB treatment $\left(\mathrm{NM}_{3}\right.$, $\left.3.64 \mathrm{t} \mathrm{ha}^{-1}\right)$ which was different from FP $\left(\mathrm{NM}_{1}, 2.96 \mathrm{tha}^{-1}\right), 100 \% \mathrm{STB}\left(\mathrm{NM}_{2}, 3.16\right.$ $\left.\mathrm{t} \mathrm{ha}^{-1}\right)$ and $20 \%$ organic amended with $80 \% \mathrm{CF}\left(\mathrm{NM}_{4}, 3.23 \mathrm{t} \mathrm{ha}^{-1}\right)$, shown in Table 2. Bell et al. (2019) and Salahin (2017) recorded increased yield of jute fibre in rice-based cropping system in strip tillage and residue retention practice. Higher yields with ST were associated with better crop establishment that was possibly due to better placement of seed and fertilizers.

\section{$2^{\text {nd }}$ Crop: T. Aman rice}

Effects of tillage and nutrient management on grain and straw yield of $T$. Aman rice

Different nutrient management showed significant variations in the grain and straw yields of T. Aman rice. No variations in the rice yields were recorded under tillage methods. The highest grain yield was produced in $20 \%$ organic amended with $80 \%$ CF $\left(6.02 \mathrm{t} \mathrm{ha}^{-1}\right)$ which was statistically similar with $25 \%$ extra of STB (5.93 t $\left.\mathrm{ha}^{-1}\right)$ and STB recommended fertilizer $\left(5.72 \mathrm{t} \mathrm{ha}^{-1}\right)$. The lowest grain yield (5.43 t 
$\left.\mathrm{ha}^{-1}\right)$ was obtained in farmers' practice, FP. Similar pattern was noticed in case of straw yield of T. Aman rice, showing the sequence as, $20 \%$ organic amended with $80 \% \mathrm{CF}>25 \%$ extra of STB $>$ STB recommended fertilizer $>$ farmers' practice (Table 4). The increase in rice yield in the study may not only be due to tillage, but also due to the combined effect of conservation tillage and nutrient management practices. Many studies have reported increased productivity of intensive ricebased systems under conservation tillage (reduced/no- tillage) with integrated nutrient management (Munda et al., 2009), but effects vary with regions due to differences in climatic and edaphic factors (Sun et al., 2010).

Table 3. Effects of tillage and nutrient management on plant height and fibre yield of jute

\begin{tabular}{l|l|l} 
of jute & \multicolumn{2}{|c}{ Fibre yield $\left(\mathrm{t} \mathrm{ha}^{-1}\right)$} \\
\hline Treatments & Plant height $(\mathrm{cm})$ & .
\end{tabular}

\section{Tillage methods}

Conventional tillage (CT)

216

3.21

Strip tillage (ST)

$218 \quad 3.29$

$\mathrm{LSD}_{0.05}$ value

Nutrient management practices

$\mathrm{NM}_{1}(\mathrm{FP})$

$\mathrm{NM}_{2}$ (STB)

$\mathrm{NM}_{3}(25 \%$ extra of STB)

229 a

$3.64 \mathrm{a}$

$\mathrm{NM}_{4}(80 \% \mathrm{CF}+20 \% \mathrm{CD})$

225 a

$3.23 \mathrm{~b}$

$\mathrm{LSD}_{0.05}$ value

$12 * *$

$0.39 *$

$$
\mathrm{CV}(\%)
$$

9.58

$\mathrm{NM}=$ nutrient management, $\mathrm{CF}=$ chemical fertilizers, $\mathrm{STB}=$ soil test basis, $\mathrm{CD}=$ cow dung, $\mathrm{LSD}=$ least significant difference at $\mathrm{P}>0.05$, ns $=$ non-significant, $*=\mathrm{P}<0.05,{ }^{*} * \mathrm{P}<0.01$

Table 4. Effects of tillage and nutrient management on the grain and straw yields of T. Amanrice

\begin{tabular}{l|c|c}
\hline \multicolumn{1}{c}{ Treatments } & Grain yield $\left(\mathrm{t} \mathrm{ha}^{-1}\right)$ & Straw yield $\left(\mathrm{t} \mathrm{ha}^{-1}\right)$ \\
\hline Tillage methods & & \\
Conventional tillage (CT) & 5.59 & 6.21 \\
Strip tillage (ST) & 5.96 & 6.94 \\
LSD & $0.28^{\mathrm{ns}}$ \\
Nutrient value & $1.34^{\mathrm{ns}}$ & \\
$\mathrm{NM}_{1}$ (FP) & & $5.79 \mathrm{c}$ \\
$\mathrm{NM}_{2}$ (STB) & $5.43 \mathrm{~b}$ & $6.12 \mathrm{bc}$ \\
$\mathrm{NM}_{3}(25 \%$ extra of STB $)$ & $5.72 \mathrm{ab}$ & $6.46 \mathrm{ab}$ \\
$\mathrm{NM}_{4}(80 \%$ CF + 20\% CD) & $5.93 \mathrm{a}$ & $6.71 \mathrm{a}$ \\
$\mathrm{LSD}_{0.05}$ value & $6.02 \mathrm{a}$ & $0.39^{* *}$ \\
\multicolumn{1}{c}{$\mathrm{CV}(\%)$} & $0.42^{*}$ & 4.91 \\
\hline
\end{tabular}

$\mathrm{NM}=$ nutrient management, $\mathrm{CF}=$ chemical fertilizers, $\mathrm{STB}=$ soil test basis, $\mathrm{CD}=$ cow dung, $\mathrm{LSD}=$ least significant difference at $\mathrm{P}>0.05, \mathrm{~ns}=$ non-significant, $*=\mathrm{P}<0.05, * *=\mathrm{P}<0.01$. 


\section{$3^{\text {rd }}$ Crop: Onion}

\section{Effects of tillage methods and nutrient management on yield and yield attributes of onion}

Tillage methods did not show any significant difference in the bulb diameter and bulb yield of onion (Table 5). However, numerically higher bulb diameter and fresh as well as sundry bulb yield of onion was recorded in minimum tillage (MT) than in conventional tillage (CT).

Different nutrient managements had significant effect on the bulb diameter and fresh as well as sundry bulb yield of onion. The highest bulb diameter of onion $(3.88 \mathrm{~cm})$ was found in $20 \%$ organic amended with $80 \% \mathrm{CF}$ which was statistically identical to $25 \%$ extra of STB $(3.87 \mathrm{~cm})$ and the lowest bulb diameter was found in farmers' practice $(3.67 \mathrm{~cm})$. Similarly, the highest bulb yield (16.0 tha hash and $13.9 \mathrm{t} \mathrm{ha}^{-1}$ sundry) was recorded in $20 \%$ organic with $80 \%$ CF followed by $25 \%$ extra of $\operatorname{STB}\left(14.6 \mathrm{t} \mathrm{ha}^{-1}\right.$ fresh and $12.5 \mathrm{t} \mathrm{ha}^{-1}$ sundry), STB recommended fertilizer(14.2 $\mathrm{t} \mathrm{ha}^{-1}$ fresh and $12.0 \mathrm{t} \mathrm{ha}^{-1}$ sundry) and the lowest bulb yield (12.7 t ha-1 fresh and $10.6 \mathrm{t} \mathrm{ha}^{-1}$ sundry) was found in farmers' practice (Table 5). No research has been done before on combined effect of tillage methods and nutrient management practices. However, Tayel et al. (2017) recorded increased bulb volume and yield under minimum tillage practices, while under conventional tillage; increased moisture stress resulted in decreased onion volume and yield.

Table 5. Effects of tillage and nutrient management on the bulb diameter, fresh and sundry bulb yield of onion at farmer's field of Rajbari

\begin{tabular}{l|c|c|c}
\hline \multicolumn{1}{c}{ Treatments } & $\begin{array}{c}\text { Bulb diameter } \\
(\mathrm{cm})\end{array}$ & $\begin{array}{c}\text { Fresh bulb yield } \\
\left(\mathrm{t} \mathrm{ha}^{-1}\right)\end{array}$ & $\begin{array}{c}\text { Sundry bulb yield } \\
\left(\mathrm{t} \mathrm{ha}^{-1}\right)\end{array}$ \\
\hline Tillage methods & & & \\
Conventional tillage (CT) & 3.74 & 13.6 & 11.4 \\
Minimum tillage (MT) & 3.84 & 15.1 & 13.1 \\
$\mathrm{LSD}_{0.05}$ value & $0.11^{\mathrm{ns}}$ & $2.8^{\mathrm{ns}}$ & $2.0^{\mathrm{ns}}$ \\
$\mathrm{Nutrient}^{\mathrm{n}}$ management & & & \\
$\mathrm{NM}_{1}(\mathrm{FP})$ & $3.67 \mathrm{~b}$ & $12.7 \mathrm{c}$ & $10.6 \mathrm{c}$ \\
$\mathrm{NM}_{2}(\mathrm{STB})$ & $3.75 \mathrm{~b}$ & $14.2 \mathrm{~b}$ & $12.0 \mathrm{~b}$ \\
$\mathrm{NM}_{3}(25 \%$ extra of STB) & $3.87 \mathrm{a}$ & $14.6 \mathrm{~b}$ & $12.5 \mathrm{~b}$ \\
$\mathrm{NM}_{4}(80 \%$ of CF $+20 \% \mathrm{CD})$ & $3.88 \mathrm{a}$ & $16.0 \mathrm{a}$ & $13.9 \mathrm{a}$ \\
$\mathrm{LSD}_{0.05}$ value & $0.09^{* *}$ & $1.1^{* *}$ & $1.1^{* *}$ \\
\multicolumn{1}{c}{$\mathrm{CV}(\%)$} & 1.97 & 5.88 & 7.36 \\
\hline
\end{tabular}

$\mathrm{NM}=$ Nutrient management, $\mathrm{CF}=$ Chemical fertilizers, $\mathrm{STB}=$ soil test basis, $\mathrm{LSD}=$ least significant difference at $\mathrm{P}>0.05, \mathrm{~ns}=$ non-significant, $* *=\mathrm{P}<0.0$. 
Integrated nutrient management is one of the most important factors that greatly influence the quality and yield of onion (Mahanthesh et al., 2009 and Bagali et al., 2012). Singh et al. (1997) reported that combined doses of organic and inorganic fertilizer (FYM $25 \mathrm{t} \mathrm{ha}^{-1}+$ NPK 100:25:25 kg ha-1) increased marketable yield. Bagali et al. (2012) noted that the combination of higher levels of inorganic with higher levels of organic fertilizers recorded higher bulb yield and the market value.

\section{Effects of tillage methods and nutrient management on cropping system productivity}

Cropping system productivity refers to the total yields of the crops (main produce) grown in sequence in the same piece of land in a year, expressed as, rice equivalent yield (REY). Between the tillage methods, strip/minimum tillage(ST/MT) numerically gave higher REY over conventional tillage (CT).

Among the different nutrient managements, the maximum REY (33.6 t ha-1) was recorded in $\mathrm{NM}_{4}$ treatment, where $80 \%$ of chemical fertilizers and $20 \%$ cowdung was applied which was statistically identical to $\mathrm{NM}_{3}$ treatment $\left(32.3 \mathrm{t} \mathrm{ha}^{-1}\right)$, where $25 \%$ extra CF of STB applied but different from $\mathrm{NM}_{2}\left(\mathrm{STB}, 30.6 \mathrm{t} \mathrm{ha}^{-1}\right)$ and $\mathrm{NM}_{1}(\mathrm{FP})$, whereas the minimum REY $\left(28.6 \mathrm{t} \mathrm{ha}^{-1}\right)$ was recorded in $\mathrm{NM}_{1}$ $(\mathrm{FP})$, as presented in Table 6 .

Table 6. Effects of tillage and nutrient management on rice equivalent yield $\left(\mathrm{t} \mathrm{ha}^{-1}\right)$

\begin{tabular}{l|c}
\hline \multicolumn{1}{c|}{ Treatments } & Rice equivalent yie \\
\hline Tillage methods & 30.2 \\
Conventional tillage (CT) & 32.3 \\
Strip/minimum tillage (ST/MT) & $2.8^{\mathrm{ns}}$ \\
$L S D_{0.05}$ value &
\end{tabular}

\section{Nutrient management}

\begin{tabular}{lc}
$N M_{1}(F P)$ & $28.6 \mathrm{c}$ \\
$N M_{2}(S T B)$ & $30.6 \mathrm{~b}$ \\
$N M_{3}(25 \%$ extra of STB $)$ & $32.3 \mathrm{a}$ \\
$N M_{4}(80 \%$ CF $+20 \% \mathrm{CD})$ & $33.6 \mathrm{a}$ \\
$\mathrm{LSD}_{0.05}$ value & $1.4 * *$ \\
\multicolumn{1}{c}{$\mathrm{CV}(\%)$} & 3.66
\end{tabular}

$\mathrm{NM}=$ nutrient management, $\mathrm{CF}=$ chemical fertilizers, $\mathrm{STB}=$ soil test basis, $\mathrm{LSD}=$ least significant difference at $\mathrm{P}>0.05, \mathrm{~ns}=$ non-significant, $* *=\mathrm{P}<0.01$.

Note: Market prices of the crops were: Tk. $20.0 \mathrm{~kg}^{-1}$ for rice, Tk. $25.0 \mathrm{~kg}^{-1}$ for onion (fresh) and Tk. $45.0 \mathrm{~kg}^{-1}$ for jute fibre. 
Yadav et al. (2017) put forward that adoption of conservation tillage and nutrient management practice involving no-tillage and integrated nutrient management along with residue retention can enhance the system productivity of the ricebased cropping system in Indo-Gangetic plains. Yadav et al. (2017) concluded that modifications of farmers' practice with inclusions of minimal disturbance of soil improved soil health and increased the system productivity by an average of $30.6 \%$.

Profitability of growing crops under different tillage methods and nutrient management in the jute-T. Aman- onion cropping system

From the first cop, jute cultivation, the highest net return $\left(64,306\right.$ taka ha $\left.^{-1}\right)$ and BCR (1.83) was obtained from strip tillage and 25\% extra of STB and the lowest net return $\left(54,129\right.$ taka ha $\left.^{-1}\right)$ and BCR (1.72) was in CT and FP combination (Table 7).

Table 7. Profitability of component crop production under different tillage methods and nutrient management at Rajbari

\begin{tabular}{|c|c|c|c|c|c|c|c|c|}
\hline \multirow[b]{2}{*}{ Particulars } & \multicolumn{4}{|c|}{$\begin{array}{c}\text { Strip tillage (ST)/Minimum tillage } \\
(\mathrm{MT})\end{array}$} & \multicolumn{4}{|c|}{ Conventional tillage (CT) } \\
\hline & $\begin{array}{l}\mathrm{NM}_{1} \\
(\mathrm{FP})\end{array}$ & $\begin{array}{c}\mathrm{NM}_{2} \\
(\mathrm{STB})\end{array}$ & $\begin{array}{l}\mathrm{NM}_{3} \\
(25 \% \\
\text { extra of } \\
\text { STB })\end{array}$ & $\begin{array}{c}\mathrm{NM}_{4}(80 \% \\
\mathrm{CF}+20 \% \\
\mathrm{CD})\end{array}$ & $\begin{array}{l}\mathrm{NM}_{1} \\
(\mathrm{FP})\end{array}$ & $\begin{array}{l}\mathrm{NM}_{2} \\
(\mathrm{STB})\end{array}$ & $\begin{array}{c}\mathrm{NM}_{3} \\
(25 \% \\
\text { extra of } \\
\text { STB }) \\
\end{array}$ & $\begin{array}{c}\mathrm{NM}_{4} \\
(80 \% \mathrm{CF} \\
+20 \% \\
\mathrm{CD})\end{array}$ \\
\hline \multicolumn{9}{|l|}{ Jute } \\
\hline $\begin{array}{l}\text { Gross return } \\
\left(\mathrm{Tk} . \mathrm{ha}^{-1}\right)\end{array}$ & 127120 & 131620 & 141450 & 132750 & 128910 & 133010 & 142820 & 134420 \\
\hline $\begin{array}{c}\text { Total input } \\
\text { cost } \\
\left(\mathrm{Tk} . \mathrm{ha}^{-1}\right)\end{array}$ & 72989 & 75218 & 77144 & 75190 & 74781 & 77010 & 78936 & 76982 \\
\hline $\begin{array}{l}\text { Net return } \\
\left(\mathrm{Tk} . \mathrm{ha}^{-1}\right)\end{array}$ & 54131 & 56402 & 64306 & 57560 & 54129 & 56000 & 63884 & 57438 \\
\hline $\mathrm{BCR}$ & 1.74 & 1.75 & 1.83 & 1.77 & 1.72 & 1.73 & 1.81 & 1.75 \\
\hline \multicolumn{9}{|c|}{ T. Aman rice } \\
\hline $\begin{array}{l}\text { Gross return } \\
\left(\mathrm{Tk} . \mathrm{ha}^{-1}\right)\end{array}$ & 120370 & 123330 & 125700 & 126630 & 116200 & 119370 & 121540 & 122660 \\
\hline $\begin{array}{c}\text { Total input } \\
\text { cost } \\
\left(\mathrm{Tk} . \mathrm{ha}^{-1}\right)\end{array}$ & 75227 & 76869 & 79686 & 77416 & 78699 & 80341 & 83158 & 80888 \\
\hline $\begin{array}{l}\text { Net return } \\
\left(\mathrm{Tk} . \mathrm{ha}^{-1}\right)\end{array}$ & 45143 & 46461 & 46014 & 49214 & 37501 & 39029 & 38382 & 41772 \\
\hline $\mathrm{BCR}$ & 1.60 & 1.60 & 1.58 & 1.64 & 1.48 & 1.49 & 1.46 & 1.52 \\
\hline
\end{tabular}




\begin{tabular}{|c|c|c|c|c|c|c|c|c|}
\hline \multirow[b]{2}{*}{ Particulars } & \multicolumn{4}{|c|}{$\begin{array}{l}\text { Strip tillage (ST)/Minimum tillage } \\
(\mathrm{MT})\end{array}$} & \multicolumn{4}{|c|}{ Conventional tillage (CT) } \\
\hline & $\begin{array}{l}\mathrm{NM}_{1} \\
(\mathrm{FP})\end{array}$ & $\begin{array}{c}\mathrm{NM}_{2} \\
(\mathrm{STB})\end{array}$ & $\begin{array}{l}\mathrm{NM}_{3} \\
(25 \% \\
\text { extra of } \\
\text { STB })\end{array}$ & $\begin{array}{c}\mathrm{NM}_{4}(80 \% \\
\mathrm{CF}+20 \% \\
\text { CD })\end{array}$ & $\begin{array}{l}\mathrm{NM}_{1} \\
(\mathrm{FP})\end{array}$ & $\begin{array}{c}\mathrm{NM}_{2} \\
(\mathrm{STB})\end{array}$ & $\begin{array}{l}\mathrm{NM}_{3} \\
(25 \% \\
\text { extra of } \\
\text { STB })\end{array}$ & $\begin{array}{c}\mathrm{NM}_{4} \\
(80 \% \mathrm{CF} \\
+20 \% \\
\mathrm{CD})\end{array}$ \\
\hline \multicolumn{9}{|l|}{ Onion } \\
\hline $\begin{array}{c}\text { Gross return } \\
\left(\mathrm{Tk} \cdot \mathrm{ha}^{-1}\right)\end{array}$ & 266000 & 298000 & 308000 & 340000 & 24200 & 270 & 276000 & 300000 \\
\hline $\begin{array}{c}\text { Total input } \\
\text { cost } \\
\left(\mathrm{Tk} . \mathrm{ha}^{-1}\right)\end{array}$ & 114802 & 122492 & 128455 & 122762 & 10987 & 117004 & 123527 & 116714 \\
\hline $\begin{array}{l}\text { Net return } \\
\left(\mathrm{Tk} . \mathrm{ha}^{-1}\right)\end{array}$ & 151198 & 175508 & 179545 & 217238 & 13212 & 152996 & 152473 & 183286 \\
\hline BCR & 2.32 & 2.43 & 2.40 & 2.77 & 2.20 & 2.31 & 2.23 & 2.57 \\
\hline
\end{tabular}

In case of T. Aman rice cultivation, the highest net return $\left(49,214\right.$ taka ha $\left.^{-1}\right)$ and BCR (1.64) was found in $20 \%$ organic amended with $80 \%$ CF $+20 \%$ CD) with non-puddling treatment (ST), while CT and $25 \%$ extra of STB combination gave the lowest BCR (1.46), as presented in Table 7. It was due to the use of higher rate of costly chemical fertilizers requirements.

In case of onion cultivation, the highest net return $\left(2,17,238\right.$ taka ha $\left.{ }^{-1}\right)$ and BCR (2.77) was found in minimum tillage and $20 \%$ organic amended with $80 \% \mathrm{CF}$, whereas farmers' tillage and nutrient practice gave the lowest net return $\left(1,32,126\right.$ taka ha $\left.^{-1}\right)$ and BCR (2.20), as shown in Table 7.It was due to lower yield obtained with the farmers' practice.

\section{Conclusions}

Different nutrient management showed significant variations on fibre yield of jute; grain yield of T. Aman rice as well as the bulb yield of onion at the farmer's field of Rajbari district. The yield and yield attributes of jute, T. Aman rice and onion responded similarly to tillage methods $(p>0.05)$. The highest fibre yield $\left(3.64 \mathrm{t} \mathrm{ha}^{-1}\right)$ of jute was obtained from $25 \%$ extra of STB and20\% organic amended with $80 \%$ CF $\left(3.23 \mathrm{t} \mathrm{ha}^{-1}\right)$ compared to STB dose $\left(3.16 \mathrm{t} \mathrm{ha}^{-1}\right)$ and farmers' practice $\left(2.96 \mathrm{t} \mathrm{ha}^{-1}\right)$. The highest grain yield of rice was produced in $20 \%$ organic amended with $80 \% \mathrm{CF}\left(6.02 \mathrm{t} \mathrm{ha}^{-1}\right)$, which was statistically similar to $25 \%$ extra of $\operatorname{STB}\left(5.93 \mathrm{t} \mathrm{ha}^{-1}\right)$ and STB dose $\left(5.72 \mathrm{t} \mathrm{ha}^{-1}\right)$. In case of onion, $20 \%$ organic amended with $80 \%$ CF outperformed yields of $16.0 \mathrm{t} \mathrm{ha}^{-1}$ fresh and $13.9 \mathrm{t} \mathrm{ha}^{-1}$ sundry than other nutrient management practices. Supplementing $20 \%$ of RFD by CD along with $80 \%$ chemical fertilizer exhibited the best performance over other treatments ( $25 \%$ extra of STB dose, STB dose and farmers' practice) in terms of crop yield and economic return. 


\section{Acknowledgement}

The authors would like to thank the NATP-2, PIU, BARC, Farmgate, Dhaka for awarding fund for the research under the project "Conservation Agricultural Practices for the Improvement of Soil health, Cropping System Productivity and Farmers' Income" to the first author.

\section{References}

Alam M.K. 2018. Assessment of soil carbon sequestration and climate change mitigation potential under conservation agriculture practices in the Eastern Gangetic Plains. PhD thesis, Murdoch University.

Alam, M.K., W.K. Biswas and R.W. Bell. 2016b. Greenhouse gas implications of novel and conventional rice production technologies in the Eastern-Gangetic plains. J. Clean. Prod. 112: 3977-3987

Alam M.K. W.K. Biswas and R.W. Bell. 2019a. Decreasing the carbon footprint of an intensive rice-based cropping system using conservation agriculture on the Eastern Gangetic Plains. J. Clean. Prod.218: 259-272.

Alam M.K. W.K. Biswas and R.W. Bell. 2019b. Increases in soil sequestered carbon under conservation agriculture cropping decrease the estimated greenhouse gas emissions of wetland rice using life cycle assessment. J. Clean. Prod.224: 72-87.

Alam M.K., N. Salahin, S. Islam, R. A. Begum, M. Hasanuzzaman, M.S. Islam andM.M. Rahman. 2016a. Patterns of change in soil organic matter, physical properties and crop productivity under tillage practices and cropping systems in Bangladesh. The Journal of Agricultural Science, 155: 216-238.

Aziz I., T. Mahmood and K.R. Islam. 2013. Effect of long term no-till and conventional tillage practices on soil quality. Soil and Tillage Research 131: 28-35.

Bagali A.N., H. B. Patil, V.P.Chimmad, P.L. Patil. And R.V. Patil. 2012. Effect of inorganics and organics on growth and yield of onion (Allium cepa L.). Karnataka Journal of Agricultural Sciences 25(1): 112- 115.

BARC. 2018: Bangladesh Agricultural Research Council 2018: Fertilizer Recommendation Guide, Soil publication number 41, Bangladesh Agricultural Research Council, Farmgate, Dhaka.

BBS (Bangladesh Bureau of Statistics). 2012. Bangladesh Bureau of Statistics, Ministry of Planning, Government of the People's Republic of Bangladesh: Dhaka, Bangladesh, 2012.

Bell R.W., M.E. Haque, M. Jahiruddin, M.M. Rahman, M. Begum, M.A.M. Miah, M.A. Islam, M.A. Hossen, N. Salahin, T.Zahan, M.M. Hossain, M.K.Alam and M.N.H. Mahmud. 2019. Conservation agriculture for rice-based intensive cropping by smallholders in the eastern Gangetic plain. Agriculture 9: 5.

BRRI (Bangladesh Rice Research Institute). 2008: BRRI Annual Research Review for 2007-08. Soil Science Division, Gazipur, Bangladesh, 48 p.

Busari M.A. andF.K. Salako. 2013. Effect of tillage, poultry manure and NPK fertilizer on soil chemical properties and maize yield on an Alfisol at Abeokuta, south-western Nigeria. Nigerian Journal of Soil Science 23: 206-218. 
Jahiruddin M.and M.A. Satter. 2010. Agricultural Research Priority: Vision- 2030 and beyond, Sub-sector: Land and Soil Resource Management. pp. 1-56.

Johansen C., M.E. Haque, R.W. Bell, C. Thierfelder and R.J. Esdaile. 2012. Conservation agriculture for small holder rain-fed farming: opportunities and constraints of new mechanized seeding systems. Field Crops Research 132: 18-32. http://dx.doi. org/10.1016/j.fcr.2011.11.026.

Kassam A. and T. Friedrich. 2009. Perspectives on nutrient management in conservation agriculture. Invited paper, IV World Congress on Conservation Agriculture, 4-7 February 2009, New Delhi, India.

Mahanthesh B., M.R.P. Sajjan, M. Harshavardhan, Vishnuvardhana and G. Janardhan. 2009. Influence of inorganic and biofertilizers on dry matter production and yield of rainy season onion (Allium cepa L.) cv. BELLARY RED. Asian Journal of Horticulture 4(1): 59-62.

Munda G.C., A. Das and D.P. Patel. 2009. Evaluation of transplanted and ratoon crop for double cropping of rice (Oryza sativa L.) under organic input management in mid altitude sub-tropical Meghalaya. Curr. Sci.96: 1620-1627.

Salahin N. 2017. Influence of minimum tillage and crop residue retention on soil organic matter, nutrient content and crop productivity in the rice-jute system. PhD. Thesis, Department of Soil Science, Bangladesh Agricultural University, Mymensingh, Bangladesh p. 246.

Singh L., S.R. Bhonde and V.K. Mishra. 1997. Effect of different organic manures and inorganic fertilizers on yield and quality of rabi onion. News Letter National Horticultural Research and Development Foundation 17(3): 1-3.

Stewart B., A. Fares Asfary, A. Belloum, K. Steiner and T. Friedrich. 2007. The proceedings of the international workshop on conservation agriculture for sustainable land management to improve the livelihood of people in dry areas. 7-9 May 2007, ACSAD \& GTZ, Damascus, Syria. 288 pp.

Sun G., S. Xu, H. Zhang, F. Chen and X. Xiao. 2010. Effects of rotational tillage in double rice cropping region on organic carbon storage of the arable paddy soil. Sci. Agric. Sin.43: 3776-3783.

Tayel M.Y., S.K. Pibars and D.S. Salama. 2017. Effect of new tillage system and soil moisture content on some onion engineering properties. International Journal of Agricultural Research 12: 156-159.

Vu D.T., C. Tang and R.D. Armostrong. 2009. Tillage system affects phosphorus form and depth distribution in three contrasting Victorian soils. Australian Journal of Soil Research 47: 33-45.

Yadav G.S., R. Lal, R.S. Meena, S. Babu, A. Das, S.N. Bhowmik, M. Datta, J. Layak and P. Saha. 2017. Conservation tillage and nutrient management effects on productivity and soil carbon sequestration under double cropping of rice in north eastern region of India. Ecol. Indic. 2017. 
